\section{Criminal conflict as collective punishment}

\section{Keisuke Nakao and Sun-Ki Chai}

$\mathrm{E}$ choing advancements in game theory, political scientists have developed theoretical explanations for why wars can happen despite the enormous resource losses they precipitate. Even if one side gains resources through war, it has been unclear from conventional international relations theories why rational actors choose to suffer the deadweight losses on both sides in actual conflict rather than to peacefully settle on the transfer of resources. Using formal models, a newer generation of political scientists have powerfully and intriguingly illustrated several processes of how bargaining breaks down and war subsequently initiates between two parties competing for the same resources (e.g., land). Theorists in related fields remain less eloquent when they address wars triggered by crime. ${ }^{1}$ For example, a report about the Nyakyusa people in Tanzania depicts communal war caused by a single cross-village wrongdoing:

"In a case of adultery the injured husband, together with his kinsmen, pursued and attempted to kill, or torture and kill, the adulterer: self-help was not only permitted but expected in this situation, and a man's near kinsmen were obliged to assist him. Neighbours were not obliged to assist in executing vengeance, but they might be victims of it, for if the injured husband did not find the adulterer he might kill any village-mate of his enemy. Such an attack commonly led to war between the two villages."2

Although actual conflict lies on a continuum between the two types, we label the former type (between competing parties) "political” and the latter (initiated by a crime) "criminal". ${ }^{3}$ Focusing on criminal conflict, this article addresses why an individual crime (e.g., robbery, cheating, adultery, and murder) can lead to brutal conflict between tribes or ethnic groups. If crime is one of the causes, then suppression of crime should reduce the risk of conflict. We thus begin by reversing the question for constructive purposes: How can crimes be deterred so that peaceful order is maintained? Regarding peaceful order as a public good, we offer a rational choice theory of peaceful order and consider why peace can be difficult to preserve in multiethnic societies. Subsequently, we explore three mechanisms of interethnic conflict and assess them with various examples.

Rational choice theory of peaceful order

Once peaceful order is established in a region, it benefits everyone there; that is, peace is nonexcludable. Because peaceful order entails positive economic externalities, it does not spontaneously emerge from free-market mechanisms. Thomas Hobbes thus maintained that peace should be provided by a central authority that monopolizes violence and polices wrongdoers. Even though contemporary political scientists agree that the provision of peaceful order is difficult without a powerful state, more recent studies have reported that peaceful order can exist even in anarchic or weak-state societies that are far beyond the control of a government. Thus, the puzzling question becomes: Just how can peaceful order be maintained without a central regime? ${ }^{4}$

Based on rational choice theory, the theory of collective action provides some clues to address this question. Collective action is possible when all participants expect an adequately large penalty to be placed on a deviant. ${ }^{5}$ For such a penalty to be credible, each member must be accessible to the rest of the group. Otherwise, a deviant may not be penalized. In addition, the group must be capable of identifying the deviant with sufficient likelihood. Otherwise, the penalty could fall on all the suspects, or at least on some of them selected at random to deter deviance. But a critical drawback with randomized punishment is that as the population grows, punishment becomes more annoying to innocents because they become more likely to be penalized for someone else's misdeeds. The result is that collective action becomes less beneficial for the group as a whole. Once the size of the group exceeds a pivotal threshold, collective action breaks down. ${ }^{6}$ Thus, the problem of identifying the deviant must be solved to enforce collective action with a sizable population. To this end, the group must retain transparency among its members. Rational choice theory thus suggests that accurate identification and effective penalization of a deviant are key to successful collective action. ${ }^{7}$ A dense social network among group members is helpful in satisfying these two requirements.

Peaceful order in multiethnic society

Where ethnic groups coexist, social networks are not uniformly distributed. In particular, an intragroup network is presumably denser than an intergroup network. Labeled "bonding" and "bridging" social capitals, ${ }^{8}$ heterogeneity of social connectedness in an ethnically mixed society may make peaceful order difficult to establish because both accessibility and transparency among individuals required for collective action are asymmetric across ethnic groups. ${ }^{9}$ Through rumors or gossip, information about an individual's culpable behavior can easily be shared among peers, but it is less likely to spread beyond ethnic borders. Lack of daily communication, periodic interactions, or common interests across groups may exacerbate the information problem. In addition, there may exist disagreements about the set of 
normative behavior among ethnic groups. ${ }^{10}$ For example, an otherwise innocent act of a Christian may be interpreted as an insult to neighboring Arabs and infuriate them. A cultural gap can destabilize an existing interethnic peaceful order.

If contention becomes a norm, it might amplify violence. In many societies, once a clansman is offended by an outsider, not only do the victim and a handful of his brothers become vengeful, but so does the community as a whole, even at the risk of retaliation. Community members who are not hurt by the offense nonetheless may take part in the punishment because of meta-norms, the willingness to punish anyone who tolerates the offender (i.e., those who do not help to enforce a norm). In this sense, an interethnic offense is a communal event even when only a few actors are directly involved. An example of meta-norms is found in 1930 Texas: A white mob angrily tried to murder a black prisoner who had attacked a white woman. In the process, the mob lynched white bystanders who refused to participate. In the Rwandan genocide of 1994, it was not only the Tutsi people who were massacred by Akazu and other Hutu extremists, but so were moderate Hutus. Small bands of ardent Hutu ethnocentrists fueled violence by agitating their peers. (Media propaganda played a critical role in the Rwandan genocide. $)^{11}$ Similarly, during the Yugoslavian wars of the 1990s, it became "virtually impossible to stay in the community without joining the violence." Rules of meta-norms have been employed by mafias and gangs, as well as by former and existing communist countries. ${ }^{12}$

Three possible mechanisms of criminal conflict

Applying the theory of collective action to multiethnic society, three hypothetical mechanisms of criminal conflict and how each accounts for peace and violent conflict are considered. In particular, we employ (1) informational, (2) preferential, and (3) functional approaches.

\section{Hypothesis 1: Lack of transparency}

The heterogeneity of social connectedness in a hybrid society presumably implies that the actions and identity of someone beyond an ethnic tie are less visible than those of co-ethnics. Homophily in particular would imply that those who share ethnic ties will be geographically closer and engage in more interactions than those who do not. A higher degree of transparency of intragroup interactions, relative to intergroup ones, characterizes a multiethnic world. This means that once a crime occurs, it is easier and less costly to identify the culprit if he is among the victim's co-ethnics. But if the victim and co-ethnics fail to identify the criminal and only identify his ethnic background (possibly through markers such as accent, language, or appearance), they cannot penalize the criminal without troubling everyone who shares his ethnic characteristics. Threat of indiscriminate vengeance, which might be rational to deter crimes, can spark large-scale violence once a crime occurs. Proper and speedy identification of the criminal matters.

But in this kind of situation, lack of transparency between and among ethnic groups can also spur criminal conflict. If the criminal remains anonymous, the only way to penalize him is to penalize all the suspects (ex ante), escalating into a spiral of reprisal.

This explanation of cross-ethnic communal violence on account of crime has limitations. For one, if identification plays a significant role in criminal conflicts, why are target groups of reported vengeance almost always ethnic groups, and not nonethnic groups? A crime investigation may merely narrow down the scope of suspects based on observable categories other than ethnicity such as sex, height, age, eye color, or people with glasses. In case that the culprit is not fully identified, an alternative penalty would fall on suspects who match a profile based on these observable categories. While the lack-of-transparency account cannot eliminate the possibility of such appearance-based penalties or conflicts, we seldom hear of a conflict between groups divided by any of these categories. Such conflicts are largely nonexistent. In addition, this account has another drawback: It cannot explain some conflicts which occurred even when the culprits were identified. ${ }^{13}$ Thus, although one cannot fully reject the lack-of-transparency hypothesis, it is not a wholly persuasive explanation.

The identification problem would be more relevant in asymmetric wars than in criminal conflicts since foreign invaders or occupiers have scarce information about the locals. For instance, American combatants in Vietnam, Afghanistan, and Iraq encountered difficulties in finding their adversaries concealed among the civilian population. ${ }^{14}$ " Two out of 10 people here hate you and want to kill you. You just have to figure out which two." ${ }^{15}$ German soldiers stationed in France, Poland, and Russia were in similar situations during the second world war when they fought partisans.

Hypothesis 2: Altruism among kinsmen

Economics assumes self-interested individuals to explain a market mechanism, but this assumption is too strong if it applies to a socially closed relationship, especially among kinsmen. Without claiming that altruism reduces conflict of interest among people and helps to preserve peaceful order — a trivial claim ${ }^{16}$ - we instead consider the claim that intraethnic altruism can catalyze interethnic conflict. To understand the role of altruism in interethnic peace and conflict, recall that an effective punishment is essential to deter deviant behavior. For a culprit who has no concern for others (a 
Success of interethnic peaceful order hinges, in part, on the quality of ingroup policing. Groups with higherquality policing can enjoy longerlasting, stable peace, whereas those with lower-quality policing tend to suffer more frequent and longerlasting disputes with other groups. purely self-interested person), vicarious punishment-the penalization of the culprit's kin-has no deterrent effect on culpable behavior. Thus, vicarious punishment is nonsensical for self-interested parties. In contrast, if people are altruistic toward their kin, vicarious punishment can be more severe and preventive than the simple, direct penalization of the culprit himself. Aware of this effect created by altruism, avengers may threaten to target both culprit and kin to show the grim consequence of culpable conduct. Although not a case of communal conflict, a similar form of vicarious punishment can be seen in North Korea, where the government detains family members of a diplomat when he is out of the country. In order to prevent the diplomat's defection, the government may send his family members to labor camps or to death, for instance via ostensible accidents, once he defects to South Korea or elsewhere. ${ }^{17}$

Although altruism creates incentives for group-wide feuds, it also facilitates the effective suppression of deviant behavior and thus assists in enforcing peaceful order. Altruism can work because rational avengers are not seeking to penalize merely for the sake of penalty but for the sake of maintaining a peaceful regime. In this sense, peace and criminal conflict are opposite sides of the same coin. ${ }^{18}$

This form of feud was reported for example among a clan of native Americans: "The Family to revenge this Death appointed one of their Tribe not to kill the Murderer, but his dearest Friend considering he would suffer more in the Death of the Person he loved than in dying himself." ${ }^{19}$ While this story illustrates the potential deterrence effect of altruism, we have not been able to locate additional such incidents. Hence, hypotheses 2 may not be so empirically relevant to the emergence of criminal conflicts.

Hypothesis 3: In-group policing

The third account focuses on functional aspects of criminal conflicts. A critical problem in enforcing interethnic peaceful order lies in the weakness of out-group networks relative to their in-group counterparts. This weakness makes out-group monitoring and controlling difficult and therefore undermines peaceful order among ethnic groups. The third hypothesized mechanism attempts to fill in the discrepancy between in-group and out-group network densities.

This account holds that once an interethnic transgression happens, the avengers may not only retaliate against the transgressor himself but also against the transgressor's ethnic fellows as a way to urge the target group to discipline its own population. Under threat of reprisal, people are motivated to monitor fellow kin and restrain them from offending outsiders since they are scared of communal war. Threat of conflict thus helps to develop an informal in-group policing regime in the target group that may contribute to interethnic peaceful order. Anthropologists have suggested the possibility that this mechanism occurs in some populations. For instance, it is reported that Eskimos around Point Barrow were so influenced by the fear of feud that any culpable behavior that could lead to violence was firmly suppressed:

"Fellow Eskimo are said to be wary of the man who stands on his rights or forces a quarrel upon others, because they have no desire to be drawn into dispute. They prefer 'a quiet man.' They attempt to deal with the determined trouble-maker by withdrawal of support and if necessary by physical expulsion."20

This pattern of group-level reprisal is consistent with rational choice theory of collective action and makes sense in at least two ways. First, mutual in-group monitoring induced by the threat of conflict can be cheaper and more effective than monitoring from outside, and in-group monitoring may help to reduce out-group offenses: Co-ethnics are in a better position to monitor themselves than ethnic outsiders. Second, because of the tight social connectedness within an ethnic group, in-group punishment can also be cheaper and more effective than individual punishment by outsiders. Peers can impose various kinds of penalties on those who misbehave. For example, social ostracism by peers or the boycotting of a business can be sufficient to discourage opportunistic transgressions. In contrast, it is likely to be more difficult and costly for outsiders to effectively restrain individual wrongdoers because of the lack or weakness of social connectedness.

For these two reasons, fellows of the victim may wage a communal vendetta against the victimizer's group because "group-level sanctions may be expected to outperform individual-level ones." ${ }^{21}$ Since co-ethnics are in a better position to monitor and control peers than are outside entities, external avengers take advantage of the insiders' position: The avengers overcome the discrepancy between intra and intergroup network densities by taking hostile actions. Moreover, this physical confrontation by outsiders may further consolidate the in-group policing regime. This in-group policing mechanism of criminal conflict is found in medieval Iceland where "group liability ... rendered the feud or fear of feud much more effective as an instrument of social control than it would otherwise have been if only the actual wrongdoer suffered the consequences of his actions."22 Because a wrongdoer is a potential danger to his neighbors, he would be purged from his village to evade the escalation of violence. According to the previously quoted report about the Nyakyusa people in Tanzania, "thieves and adulterers were liable to be banished from a village just like witches and sorcerers, for they too brought misfortune on their fellows." 23 This sort of social ostracism may work as a penalty to suppress culpable behavior. 
To summarize, out-group peaceful order is enforced by in-group policing while in-group policing is induced by out-group conflict. Although it cannot be asserted that the third mechanism always applies, it is richer in supportive incidents than the two others. Here are three additional examples of this mechanism at work: T.E. Lawrence (Lawrence of Arabia) reported in his autobiography that, on the way to see Faisal, the future king of Iraq, he met an Arab man who was excluded from his community and lived alone because he had murdered a Christian. ${ }^{24}$ We have also located in-group policing mechanisms in Poland and the Ottoman empire which afforded a considerable degree of autonomy to ethnic minorities. ${ }^{25}$

In-group policing of interethnic criminal conflict suggests that the success of interethnic peace hinges on each group's quality of policing. Groups with higher quality policing can enjoy long-lasting and stable peace, whereas those with lower quality policing tend to suffer more frequent and longer disputes with other groups. In the absence of Leviathan, in-group policing can play a decisive role in maintaining a peaceful order. Without effective in-group policing, conflict might be inevitable.

Collective punishment in modern society

Applications of the in-group policing regime and collective punishment idea can be broadly observed even in modern society where individual rights are highly respected. In a production team, for example, workers' individual performance is often evaluated in the context of the group. When compensation is linked among the workers, the free-rider problem can be alleviated through mutual monitoring and peer pressure. An employer can exploit internal incentives to ensure team spirit and promote productivity. ${ }^{26}$ Group lending, used in microcredit banking, is another instance. Because debtors are jointly liable, they tend to encourage each other's scheduled repayment. ${ }^{27}$ Similarly, editors of scholarly journals may rely in part on coauthors of submitted manuscripts to repress academic misconduct. Because journal editors cannot readily tell which coauthor committed an offense such as plagiarism, they put the blame on all coauthors when an offense is revealed. In light of the risk of this shared blame, coauthors are motivated to discipline each other or blow the whistle. Other examples of collective punishment can be seen in politics and business: In Britain and in Japan a councilor loses his seat in Parliament if the councilor's secretary conducts a criminal act such as bribe; in corporate governance, shareholders are liable for the torts and crimes of their corporation. These examples illustrate how collective punishment can work to police social ills and serve the collective good. When selective and individual punishment on a defector is unavailable, ineffective, or overly costly, collective punishment can emerge as a second-best method on functional grounds. ${ }^{28}$

\section{Conclusion}

Based on a rational choice theory of collective action, the article presents three hypothetized accounts for cross-communal conflict induced by criminal acts: (1) informational; (2) preferential; and (3) functional. For all three, the disparity in density between intra and intergroup networks is the key obstacle undermining intergroup peaceful order. Although focused on interactions between ethnic or tribal groups, the theory can apply to other kinds of informal groups or organizations such as gangs. Gangs have kinship-like characteristics such as recognizable physical and cultural traits (e.g., colors and hand signs), demarcated geographical zones (i.e., turfs), and norms that dictate preferential treatment to group members.

Hypothesis 1 explains escalation of communal violence in terms of the identification of an interethnic transgressor. Hypothesis 2 holds that interethnic retaliation is collective because avengers exploit altruistic concerns among kinsmen to discourage intergroup opportunism. Hypothesis 3 maintains that external confrontation between tribal or ethnic groups is called for to develop internal social control within each group. Although the first two hypotheses cannot be fully rejected, the third is most closely associated with reported incidents.

\section{Notes}

Keisuke Nakao, the corresponding author, is an assistant professor of economics at the University of Hawaii, Hilo, Hawaii, USA. He may be reached at keisuken@hawaii.edu. Sun-Ki Chai is an associate professor of sociology at the University of Hawaii, Manoa, Hawaii, USA. He may be reached at sunki@hawaii.edu. The authors acknowledge financial support from the Office of Scientific Research, U.S. Air Force (AFOSR Contract FA9550-07-1-0253). We would like to thank Thanh-Nghi Nguyen, Masatoshi Tsumagari, and Abigail Carroll for helpful comments. All errors are our own.

1. Exceptions include Fearon and Laitin (1996); Bendor and Mookherjee (2008); Nakao (2009).

2. Quoted from Wilson (1983, p. 149). Another example is from southern Egypt, where a Christian shopkeeper's insult to a Muslim, and the refusal to apologize, led to interethnic turmoil (The Economist, 8 January 2000).

3. This categorical distinction between political and criminal conflicts follows Chabal and Daloz (1999, p. 83). 
(C) www.epsjournal.org.uk - Vol. 6, No. 1 (2011)

4. Philosopher: Hobbes (2009). Contemporary: The most notable work exploring this argument is Horowitz (1985). More recent studies: For instance, Fearon and Laitin (1996); Bowen (1996); Gould (1999). Jha (2007) offers an alternative explanation for peace across ethnic lines.

5. Imagine a repeated n-person prisoner's dilemma game. The “folk theorem” in repeated game theory (e.g., Fudenberg and Maskin 1986) demonstrates that cooperation can emerge through tacit coordination even without a commitment device, such as court system, to punish free-riders.

6. For a theoretical examination of this prediction, see Bendor and Mookherjee (1987).

7. For more detailed argument, see Hechter (1984; 1987).

8. According to Putnam (2001, pp. 22-24), although there is no reliable and comprehensive measure to distinguish between bonding and bridging social capitals, they are conceptually different. The former is exclusive or inward-looking (exemplified by ethnic fraternal organizations and church-based women's reading groups), whereas the latter is inclusive or outward-looking (e.g., civil rights movements and internet chat groups).

9. These points are also noted by Hardin (1995, pp. 118-9): "First, groups are apt to have better information about their members' actions than about the actions of people in other groups. Second, groups are apt to have fairly straightforward reasons for imposing order on their own members if they are to be held responsible for their fellow members' actions."

10. Hechter (1987, p. 178) argues that cultural disparities tend to generate misinterpretation of behavior.

11. There are plenty of reports and some scholarly writing on how two radio stations in particular, Radio Rwanda and Radio Télévision Libre des Mille Collines (RTLM), spread messages urging Hutus to murder Tutsis. See Kellow and Steeves (1998); Thompson (2007).

12. Texas: This episode appears in Axelrod (1986). Rwanda: See Des Forges (1999) for the causes and consequences of the Rwandan genocide. Ardent: Mueller (2000) argues that ethnic wars are often waged by small groups of thugs. Yugoslavia: Hardin (1995, p. 23). Meta-norms in communist societies are mentioned in Axelrod (1986, p. 1101). Also see Bronfenbrenner (1970); Meyers and Bradbury (1968). For gangs, see, e.g., Cohen (1990, p. 14), Horowitz (1990, pp. 47-48), Sánchez Jankowski
(1991).

13. This form of an incident can be seen among the Nyakyusa. Moore (1978, p. 104) reported: "Intervillage adultery cases sometimes blew up into intervillage war, when the wronged husband and his supporters killed a covillager of the adulterer in reprisal.” The target of vengeance is not the adulterer himself but his covillager. Reid (1999, p. 93) also reported a case among North American Indians.

14. See Kalyvas (2006, pp. 89-91).

15. See Zucchino (2004).

16. In contrast, Bernheim and Stark (1988) and Nakao (2008) argue that altruism may not necessarily assist collective action.

17. The defection of Hwang Jang-yop, a developer of the North Korean state ideology, Juche Idea, seems to have provoked similar consequences (McDonald and Su-Hyun 2010).

18. In this sense, the rational choice theory of criminal conflicts mirrors Gluckman's (1955) conflict theory in anthropology.

19. From Nicholas Garry's diary as quoted in Reid (1999, p. 93). Another incident which supports hypothesis 2 might be Israel's policy of demolishing houses of Palestinian suicide bombers and their families. However, an Israeli army committee more recently acknowledged that the deterrent effect was limited (Myre, 2005).

20. Colson (1974, p. 41).

21. The mechanism of collective sanctions is well explained in Levinson (2003).

22. Miller (1990, p. 197).

23. See note 2 .

24. Lawrence (1935).

25. Dubnow (1916, pp. 103-106, 188-193) reported that Jews maintained an autonomous community in Poland. In contrast, Dumont (1982, pp. 221-230) showed that Jews suffered from constant persecution by other ethnic groups in the Ottoman empire. 
(C) www.epsjournal.org.uk - Vol. 6, No. 1 (2011)

26. Kandel and Lazear (1992) point out the relative merit of the joint performance evaluation in team production.

27. For a theoretical account for the peer pressure among debtors, see Banerjee, Besley, and Guinnane (1994).

28. Commenting on a related context, Greif (1994) argues that compared to the individualist culture among the Latin Genoeses, the collectivist culture among the Muslim Maghribis played a significant role in fostering institutions exercising collective sanctions.

\section{References}

Axelrod, A. 1986. “An Evolutionary Approach to Norms.” American Political Science Review. Vol. 80, No. 4, pp. 1095-1111.

Banerjee, A.V., T. Besley, and T.W. Guinnane. 1994. “Thy Neighbor’s Keeper: The Design of a Credit Cooperative with Theory and a Test.” Quarterly Journal of Economics. Vol. 109, No. 2, pp. 491-515.

Bernheim, B.D. and O. Stark. 1988. "Altruism with the Family Reconsidered: Do Nice Guys Finish Last?” American Economic Review. Vol. 78, No. 5, pp. 1034-1045.

Bendor, J. and Mookherjee, D. 1987. "Institutional Structure and the Logic of Ongoing Collective Action.” American Political Science Review. Vol. 81, No. 1, pp. 129-154.

Bendor, J. and D. Mookherjee. 2008. “Communitarian versus Universalistic Norms.” Quarterly Journal of Political Science. Vol. 3, No. 1, pp. 1-29.

Bowen, J.R. 1996. “The Myth of Global Ethnic Conflict.” Journal of Democracy. Vol. 7, No. 4, pp. 3-14.

Bronfenbrenner, U. 1970. Two Worlds of Childhood: U.S. and U.S.S.R. New York: Russell Sage.

Cohen, A.K. 1990. “Foreword and Overview.” In C.R. Huff, ed. Gangs in America. New York: Sage Publications, Inc.

Chabal, P. and J. Daloz. 1999. Africa Works: Disorder as Political Instrument. Bloomington, IN: Indiana University Press.

Colson, E. 1974. Tradition and Contract. Chicago: Aldine.

Des Forges, A.L. 1999. “Leave None to Tell Story: Genocide in Rwanda.” New York: Human Rights Watch.

Dubnow, S.M. 1916. History of the Jews in Russia and Poland. Vol. 1, Trans. Friedlaender, I., Philadelphia: Jewish Publication Society of America.

Dumont, P. 1982. "Jewish Communities in Turkey during the Last Decades of the 19th Century.” In B. Braude and B. Lewis, eds. Christians and Jews in the Ottoman Empire. Vol. 1. New York: Holmes and Meiler.
[Economist] 2000. “Egypt’s Vulnerable Copts.” The Economist. 8 January, p. 41.

Fearon, J.D. and D.D. Laitin. 1996. “Explaining Interethnic Cooperation.” American Political Science Review. Vol. 90, No. 4, pp. 715-735.

Fudenberg, D. and E. Maskin. 1986. "The Folk Theorem in Repeated Games with Discounting Or With Incomplete Information.” Econometrica. Vol. 54, No. 3, pp. 533-554.

Gluckman, M. 1955. Custom and Conflict in Africa. Glencoe, IL: The Free Press.

Gould, R.V. 1999. "Collective Violence and Group Solidarity: Evidence from a Feuding Society.” American Sociological Review. Vol. 64, No. 3, pp. 356-380.

Greif, A. 1994. "Cultural Beliefs and the Organization of Society: A Historical and Theoretical Reflection on Collectivist and Individualist Societies.” Journal of Political Economy. Vol. 102, No. 5, pp. 912-950.

Hardin, R. 1995. One for All. Princeton, NJ: Princeton University Press.

Hechter, M. 1984. "When Actors Comply: Monitoring Costs and the Production of Social Order.” Acta Sociologica. Vol. 27, No. 3, pp. 161-183.

Hechter, M. 1987. Principles of Group Solidarity. Berkeley, CA: University of California Press.

Hobbes, T. 2009. Leviathan. New York: Oxford University Press.

Horowitz, D. 1985. Ethnic Groups in Conflict. Berkeley, CA: University of California Press.

Horowitz, R. 1990. “Sociological Perspectives on Gangs.” In C.R. Huff, ed. Gangs in America. New York: Sage Publications, Inc.

Jha, S. 2007. "Maintaining Peace Across Ethnic Lines: New Lessons from the Past.” Economics of Peace and Security Journal. Vol. 2, No. 2, pp. 88-93.

Kalyvas, S.N. 2006. The Logic of Violence in Civil War. New York: Cambridge University Press.

Kandel, E. and E.P. Lazear. 1992. "Peer Pressure and Partnerships.” Journal of Political Economy. Vol. 100, No. 4, pp. 801-817.

Kellow, C.L. and H.L. Steeves. 1998. "The Role of Radio in the Rwandan Genocide.” Journal of Communication. Vol. 48, No. 3, pp. 107-128.

Lawrence, T.E. 1935. Seven Pillars of Wisdom. Garden City, NJ: Doubleday, Doran \& Company, Inc.

Levinson, D.J. 2003. “Collective Sanctions.” Stanford Law Review. Vol. 56, pp. 345-428.

McDonald, M. and L. Su-Hyun. 2010. “Seoul Arrests Alleged N. Korean Spy.” The New York Times. 20 October.

Meyers, S.M. and W.C. Bradbury. 1968. "The Political Behavior of Korean and Chinese Prisoners of War in the Korean Conflict: A Historical Analysis.” In S.M. Meyers and A.D. Briderman, eds. Mass Behavior in Battle and Captivity: The Communist Soldier in the Korean War. Chicago, IL: University of Chicago Press.

Miller, W.I. 1990. Bloodtaking and Peacemaking. Chicago, IL: The University of Chicago Press. 
(C) www.epsjournal.org.uk - Vol. 6, No. 1 (2011)

Moore, S.F. 1978. Law as Process: An Anthropological Approach. London: Routledge.

Mueller, J. 2000. “The Banality of ‘Ethnic War'.” International Security. Vol. 25, No. 1, pp. 42-70.

Myre, G. 2005. "Israel Halts Decades-Old Practice of Demolishing Militants' Homes.” The New York Times. 18 February.

Nakao, K. 2008. “Can Altruism Hinder Cooperation?” Economics Bulletin. Vol. 4, No. 26, pp. 1-6.

Nakao, K. 2009. “Creation of Social Order in Ethnic Conflict.” Journal of Theoretical Politics. Vol. 21, No. 3, pp. 365-394.

Putnam, R. 2001. Bowling Alone: The Collapse and Revival of American Community. New York: Simon \& Schuster.

Reid, J.P. 1999. Patterns of Vengeance. Ninth Judicial Circuit Historical Society.

Sánchez Jankowski, M. 1991. Islands in the Street: Gangs and American Urban Society. Berkeley, CA: University of California Press.

Thompson, A. 2007. The Media and the Rwanda Genocide. London: Pluto Press.

Wilson, M. 1983. Good Company. Westport, CT: Greenwood Press.

Zucchino, D. 2004. "Sorting Friends from Foes.” Los Angeles Times. 1 November, AI, A8-A9. 